\title{
Planting Poetry: sowing seeds of creativity in a year 5 class
}

\section{Introduction}

In an international comparative study of curriculum documents across the European Union, Wyse and Ferrari (2014) demonstrate that, rhetorically at least, creativity has become a common feature of education policy in all twenty-seven member states. Exactly what is meant by 'creativity' in these documents, however, begs several questions, particularly since those definitions most common in current educational discourse emerge out of contradictory philosophies and intellectual traditions. These might range, for example, from socio-cultural understandings of creativity as something that is both emancipatory and collaborative through to business-inflected versions of entrepreneurial activity (Jones, 2011). Here in England the National Curriculum, as revised in 2014, is framed by a statement which claims 'human creativity' to be a central component in preparing young people for future citizenship (DfE, 2014, paragraph 3.10):

The national curriculum provides pupils with an introduction to the essential knowledge they need to be educated citizens. It introduces pupils to the best that has been thought and said, and helps engender an appreciation of human creativity and achievement.

Yet, this view of creativity constructs it as the preserve of specially gifted individuals, whose canonised examples of genius are merely to be 'appreciated'; what it omits to suggest is that creativity might be a productive or, indeed, a critical activity in which young people are themselves actively engaged. Beyond this framing statement, the current version of the National Curriculum has little else to say about creativity, particularly in its (re-)construction of English following the removal of creativity as one of four principles underpinning the whole subject, as was the case in the previous iteration (see QCA, 2007). Consequently, space for creative activity within the narrow constraints of a standards-based curriculum has become increasingly tight, especially so for a heavily regulated 'core' subject like English, despite calls by influential bodies such as the National Advisory Committee on Creative and Cultural Education for education policy to recognise the importance of unlocking every young person's creative potential across the whole curriculum (NACCCE, 1999).

Since publication of All our Futures, NACCCE's landmark report into education and creativity (1999), schools have developed a variety of strategies to enhance young people's opportunities to be creative, often through special projects located in uncertain spaces on the margins of the formal curriculum (Hall \& Thomson, 2007). 'Planting Poetry', the focus of this article, is one such project, the result of a partnership between a creative writing organisation, the Ministry of Stories (MoS), and a year 5 class in a north-east London primary school. I want to offer an account of what happened when this particular group of diverse learners and their teacher worked collaboratively and inclusively with a writer- 
storyteller on a five week poetry-writing project. This article arises out of a case study I carried out as part of a larger research project, a three-year mixed method evaluation of the work of the MoS, conducted between 2012-15 by a team of researchers from the Digital|Arts|Research|Education group (DARE) based at UCL's Institute of Education (see Wyse et al, 2015). Each year, a small number of MoS creative writing projects were selected as subjects for in-depth case studies, the purpose of which was to contribute rich qualitative data to the longitudinal evaluation.

In this article, I attempt to explore the nature of the creative activity on offer and also raise some questions about the role of creative practitioners working in partnership with schools. In the project's focus on nature, the environment and community, it might be seen to have much in common with 'eco-critical' approaches to writing poetry (see, for example, Matthewman, 2013), particularly in its exploration of place across a range of locales. Indeed, a key feature of the project was the use made of various physical spaces in and around the children's Victorian primary school building, including a little-used roof-top playground and a nearby community garden. What I hope to show is the way this project broke free of the classroom walls both physically and metaphorically.

\section{Defining creativity}

Banaji et al (2010) identify at least nine different 'rhetorics' of the term 'creativity' in current usage, although the authors point out that in practice 'creativity' is usually situated somewhere midway between what could be characterised as elitist or democratic extremes. Across the different disciplinary perspectives Wyse and Ferrari (2014) argue that originality and value emerge as two significant definitional concepts, although the requirement to achieve originality in an absolute sense in any artistic field might be seen to work against a democratic view of creativity; this becomes a particularly problematic proposition when applied to activities and artefacts produced by school children. Similarly problematic is the notion of value, which from a 'traditionalist' perspective (Banaji et al, 2010,15) could be normally expected to rely on the judgement of recognised experts, those with finely attuned aesthetic sensitivities. Consequently, Wyse $(2014,6)$ develops a more expansive conception of originality, one which is of more use to those working within educational contexts:

My view of originality recognises that all creative processes, products, acts derive from a history in their respective context, fields, and traditions and so to some degree are imitative...even a young child in the production of, for example, a piece of writing can produce something that is original to them.

Taking this a stage further, Jones and Wyse (2013) argue that judgements about whether a piece of creative work is 'of value' can be made by children and young people themselves alongside their teachers and families. 
Consistent with this approach, a significant feature of the DARE research is that judgements about imaginative adaptation, originality and value are made consensually through dialogue between the teacher and researcher and by the children themselves. As part of this process, a 'consensual creativity tool' was developed by the Principal Investigators for the purpose of attempting to assess the degree to which young participants' creativity had been enhanced by the project (for a fuller explanation, see Wyse et al, 2015).

Whilst the MoS website (see ministryofstories.org) does not explicitly locate its work and philosophy in any one theoretical tradition, statements of intent suggest that as an organisation its understanding of creativity is similar to that promoted by All our Futures (NACCCE, 1999, 29), summarised as 'imaginative activity fashioned so as to produce outcomes that are both original and of value'. This definition underpinned the work of 'Creative Partnerships', the flagship New Labour initiative introduced in the wake of the NACCCE recommendations (but abolished by the newly elected Coalition Government in 2010). By implication, at the heart of MoS philosophy lies a fundamental democratic belief in the capacity of all young people to 'realise their own creative potential', with attention paid to both the processes ('making writing fun and accessible') and to the outcomes (providing 'publishing platforms'). By aiming to 'challenge aspirations' and foster 'self respect' the MoS constructs creative activity as a social good, even an inclusive process leading to social cohesion ('powerfully motivating disengaged students').

\section{The project}

The Ministry of Stories (MoS) is a creative writing and mentoring centre located in east London whose central mission is to enhance the writing, motivation and creativity of young people aged between 8 and 18 years of age. The MoS was founded by writers Nick Hornby, Lucy MacNab and Ben Payne in 2010, inspired by writing centres in the USA such as Valencia 826 in San Francisco led by Dave Eggers. Clubs and workshops are provided at the centre itself, whilst MoS staff also work with local schools and other organisations offering a range of bespoke projects, many of which, like Planting Poetry, employ professional writers and other arts practitioners.

The Planting Poetry project took place one afternoon per week during the normal school day, led by the professional writer-storyteller (Sally) ${ }^{1}$ and assisted by a member of the MoS staff (Viv), three or four volunteer MoS mentors, the class teacher (Lynne) and a teaching assistant. The children explored the community garden through storytelling, nature-themed word-games, drama activities and drawing. Adults and children together shared personal stories connected with nature and not only planted real seedlings but also made-up wishes in the shape of brightly coloured glass 'jewels'. Sally read poems aloud and introduced the children to different poetic forms. Alongside the fun and games, periods of quiet reflection in the garden often preceded writing; children sometimes wrote poems together and 
sometimes individually. Finally, there was an end of project celebratory event (what the children called their 'poetry party') held in the garden to which parents and carers were invited and at which children performed one of the poems they had composed. To the obvious delight of the children and their families some of the children's poems had been converted by an artist (commissioned by the MoS) into a semi-permanent garden installation which, at the time of writing, remains in place (see Figure 1).

\section{[figure 1 to come somewhere near here]}

For the case study I carried out pre- and post-project interviews with the class teacher and a sample of six children from the year 5 class. The sample of three girls (Salma, Aminah, Laura) and three boys (Sammy, Tomek, Tyler) was selected by the class teacher to reflect the gender, ethnic diversity and attainment range of the class as a whole. My observations of the formal workshop sessions were recorded through a combination of field notes and photographs. Finally, writing produced by children in the sample was analysed by the teacher and me together, focusing on the level to which we agreed that each piece (and the process of production) reflected imaginative adaptation of existing ideas; originality or 'newness'; and value, headings taken from the 'consensual creativity tool' framework. As part of this conversation, we compared the selected piece(s) of project writing with a piece completed by each child as part of normal classwork preceding the project.

I transcribed and thematically analysed audio recordings of interviews (Miles \& Huberman, 1994). I initially organised the data according to themes which arose out of the overall MoS evaluation research questions (motivation for writing, the development of writing, enhancing creativity), with additional themes emerging as the data were analysed (in this case, inclusion).

\section{How the project developed children's writing}

Sally and Viv made use of a wide range of strategies to stimulate ideas and to develop the children's writing, including drama, storytelling, games, word puzzles, personal anecdote and group readings. In the initial stages frames were provided to support collaborative composition (for example, grids on A3 paper to help the children grasp a basic 'mesostic' structure - where the title or theme of the poem runs vertically through the middle of the horizontal lines, see figure 2), but children were not restricted to specific poetic forms as the project progressed. In fact a key feature of the project overall was, according to Lynne, that children were 'independent in their decisions and took ownership of their material' and several children commented at the end that they had enjoyed an unusual degree of choice over their writing.

[figure 2 to be placed somewhere near here] 
When reflecting on the project, Lynne suggested that poetry had been a good area of focus particularly for those children who did not find writing easy, because as she pointed out poetry at this level generally has a shorter length than story writing - 'they know when it ends'- and a 'finite structure', making it 'less scary'. She lamented the paucity of opportunities to explore poetry 'for its own sake' within the increasingly SATs-dominated curriculum in year 5 , echoing a similar point made by Ofsted (2007) in its own investigation into the teaching of poetry in schools. The poetic structures on offer during the project included Sally's own 'invocation' poem which viewed nature from the perspective of an object found in the garden (making use of patterned line openings 'I am...; I have been; I know...'); and mesostic poems, a form which, appropriately enough for a garden-focused project, is sometimes compared to branches growing out of a central trunk. From observations of the children at work during workshop sessions, mesostic poetry appeared to have offered them a certain freedom from formal grammatical structures in that they could play around with a series of (semi-)connected ideas and phrases, enabling a pupil such as Sammy, for example, to become imaginatively engaged at a more conceptual level (see below).

Significantly, Lynne was keen to embed the project into the wider curriculum, making space for children's writing at other points in the week. This left Sally with greater scope for pursuing exploratory activities during her workshop sessions rather than feeling tied to written outcomes. For example, at the end of the first session she performed her invocation poem to the children whilst in the garden, inviting them to write as if from the perspective of their own chosen object before the next session. Lynne subsequently used the text of the poem 'as a starting point' with the class the next day. In Lynne's words, the pupils responded positively because the poem 'was imbued with the magic of the garden'.

The garden was cited as a genuine source of inspiration by all pupils interviewed at the end of the project. For example, Tomek commented: 'It helped going to the garden itself because you could see the plants and you could ... actually visualise how to describe it.' Aminah talked about the combination of being in the garden and being supported by Sally as helping her engage imaginatively in the writing process:

When I went [to the garden] and I couldn't find a plant to do it, and I was really sad and then [Sally] came up to me and she said, what plant would you like and I said I don't know. And she said to me look carefully. And I found a little black grassy type of plant, and I said I wanted to do that...And she said what's it called? And I said midnight because it was black. And that was my middle word!

Later in the interview Aminah attempted to describe the supportive way in which Sally worked with them: 'She says things in a tone, like she really wants to know what you're doing', reminiscent of the 'facilitative stance' frequently adopted by creative practitioners in schools as noted by Burnard and Swann $(2010,72)$. Indeed, Galton's research (2010) 
suggests that one of the ways in which creative practitioners successfully motivate pupils in schools is by treating them as 'co-learners', a trait noticeable in Sally as she talked with and worked alongside pupils either in the classroom or in other locales.

In pre-project interviews only two pupils, Sammy and Tyler, had openly expressed a dislike of writing. Sammy had been selected for the case study by Lynne as a high achieving pupil who was nevertheless reluctant to engage imaginatively in English, thus finding it difficult to develop his writing and move onto the next National Curriculum level. By the end of the project Sammy's attitude to writing appeared to have undergone considerable change. What clearly struck Sammy as most surprising about the project was the degree to which he had been able to exercise choice and agency in his writing. As he said to me in the postproject interview:

I thought it would be in class, they were going to tell us stuff and then we had to write a poem about it, but we were more free and had the choice about what to write about...I think I'm better at poetry now, because you can focus on anything.

Sammy also picked out the 'poetry party' as a highpoint of the experience. Lynne's view was that 'showcasing' at the end of the project was crucial to the project as a whole; as she said, the performance in the garden at the end gave their writing 'real value'. The children took responsibility for organising the event, designing invitations, making lemonade and even creating a poem-based lucky dip - activities which helped stimulate enthusiastic preparation for their poetry performances.

In interview Lynne felt that Sally's one-to-one support for the performance aspect of the finale had a 'very positive impact' on the children in terms of their motivation. The normally shy Aminah described to me the way in which Sally helped her overcome her customary stage-fright, clearly deriving a new sense of self confidence from the experience. Aminah also gained enormous self-esteem from seeing her poem as part of the installation:

I came in the garden, and I was walking around...and then I saw it! And then I saw it was exactly the same, and it was mine! And I was shocked because I thought mine was rubbish....and I felt really good.

Aminah ended her post-project interview by telling me that as a result she had even started to write poems at home: 'My mum knew I hated poetry and she was, like, wow, you've really improved'.

In his pre-project interview Tomek talked enthusiastically about science and maths, his favourite school subjects. Although his liking for writing was qualified ('Well, I do like it sometimes'), the Planting Poetry project appeared to have successfully linked together his scientific interest ('I like making experiments and lots of fun stuff'), previous curriculum work covered by Lynne on life cycles, and his creative impulses (making his own creations 
out of Lego at home). In his post-project interview Tomek hinted at this convergence of interests:

JC: Do you think your writing has changed in any way?

Tomek: Kind of because I was good at poem before the workshop but I think it got me kind of more creative...just writing about a place and like real living things. And when I was writing other poems they was about made up stuff, but now I write real poems about stuff that exists.

By chance, the class went on a visit to Kew Gardens as part of their science curriculum during the period of the project. Tomek was one of a number of pupils who felt inspired to write a poem about the trip when he got home. He picked this out as one of the pieces of writing he was most proud of, along with the poem he performed at the poetry party: 'I really liked them because they weren't just poems, they were about the garden, about nature and they were really good written'. Previously Tomek had been described by Lynne as a boy who 'is fascinated by the world around him, and stuff, and facts. But not writing'. For Tomek the project appeared to have provided him with a purpose and a context for his creative writing, particularly by construing poetry as a medium suited to explorations of the real world around him (Barrs and Styles, 2013).

\section{Enhancing Creativity}

As already stated, one aim of the broader research project was to attempt to evaluate the effectiveness of MoS activities in enhancing participants' creativity. Adhering to the methodology adopted by the wider research project, Lynne and I compared pieces of creative writing completed before the project began with writing each case study pupil had written during the project. It is perhaps telling that all of the available creative writing produced by pupils so far in year 5 was in prose form, influenced by the requirements of the end of Key Stage 2 national tests (taken annually by children in year 6 ). This meant that we were not only comparing the children's project poems with writing produced for formal assessment but also across written forms - poetry and prose - in the latter case, a story entitled 'A strange occurrence at playtime'. Whilst drawing any firm conclusions about the degree to which children's creativity had been enhanced would be problematic, I would argue that the reflexive nature of the professional dialogue arising out of the process was of value in itself.

For someone who had claimed to strongly dislike writing, Sammy's poetic achievements while on the project were impressive and contrasted significantly with his assessed school piece of writing. The latter, a conventional school story, focused very much on the everyday world he was familiar with; technically correct, it showed signs of being carefully and consciously composed as an assessment piece. As Lynne commented, 'Writing's not his bag...It doesn't feel as if his heart and soul is in the story at all'. Or as Doecke and 
MacClenaghan $(2011,8)$ might put it, Sammy had not had the opportunity thus far to 'find himself' in the highly regulated Key Stage 2 English curriculum. For Sammy, the physical experience of visiting the garden allied with Sally's playfulness with words appear to have helped him break away from the stranglehold of assessment-focused conventions. In his version of Sally's 'invocation' poem, he wrote from the perspective of the object he selected from the garden, a softly textured leaf which he named 'Life's leaf blanket'. The poem (see figure 3) takes some of Sally's original ideas, such as the patterning of each stanza and the juxtaposition of opposites, reworking them in interesting ways. Both Lynne and I particularly liked the increasingly metaphysical line of thought which can be traced through the final stanza:

[figure 3 to be placed somewhere near here]

Afterwards in interview, Sammy said that he had found the final stanza of the poem the most difficult to write - yet he felt sufficiently motivated to spend at least 20 minutes in class drafting the final part. Like Tomek, on return from the Kew Garden trip Sammy voluntarily wrote a lengthy poem in celebration. Nevertheless, he picked out the mesostic poem he composed for the poetry party as the one he was most proud of. Entitled 'NATURE', it is also the poem which Lynne felt 'crystallised everything' about the project, synthesising the garden experience, new ways of thinking about science, philosophy and poetic form:

\author{
A breezy wiNd whispers \\ in All the trees \\ the flowers siT waiting for the bees \\ plants sway and Utter their speech \\ it's so soft to ouR ears it cannot reach \\ NaturE has its own ways to humans it won't teach
}

Sammy told me that his inspiration for the opening line came directly from sitting on a rock in silence in the garden and suddenly being aware of the sound of the breeze. He wanted to be deliberately thought provoking in the way he wrote about nature as a force of mystery. Performing the poem as part of a collective event was for him the highlight of the project.

\title{
Inclusivity
}

Lynne's year 5 class fully reflected the diverse ethnic and social mix of this part of London. Given that children were normally streamed for literacy lessons across the two parallel year 
5 classes, a significant feature of the Planting Poetry project was the way in which Sally worked inclusively with Lynne's pupils, making clear at the first briefing session her assumption that everyone could participate and find ways of expressing themselves creatively regardless of their National Curriculum level. This principle of inclusivity was adhered to across all observed sessions. Although not one of the original case study pupils, Kashif, a boy formally statemented for his special educational needs, provided an interesting illustration of how this worked.

Kashif's name was first raised at the pre-project planning meeting, with Lynne describing him as being very weak academically and warning Sally that he was someone who 'will struggle with using his imagination'. In response, Sally immediately stated her intention to 'include him as I would everyone else', an agreed approach which she subsequently repeated for the benefit of volunteer mentors during their later briefings. It was apparent throughout the observed sessions that Kashif was able to engage in ways which worked for him, sometimes supported by his dedicated Learning Support Assistant (LSA), but often working more independently. During the introductory visit to the garden, Kashif became fascinated by a ladybird he found, which resulted in him carefully drawing a colourful picture of it later in the week in his MoS notebook and then writing a lengthy poem about life from the perspective of it with the help of his LSA. As Lynne said in the post-project interview, there was a 'level of real pride in what he achieved during the project'. His garden-themed mesostic poem 'FLOWERS' was selected by Viv to be part of the end of project installation (see figure 4), a matter of enormous surprise and delight to Kashif himself. Lynne described his reaction when he entered the garden at the final event and caught sight of his poem:

Kashif was overwhelmed by the idea of his [flowers] poem on the signs...he was staring at the poem in his book, then staring at the sign - doing this completely by himself. In his questionnaire he said that the very best thing about the project was having his poem published in the garden...

[figure 4 to be placed somewhere near here]

Lynne appreciated that Sally had given Kashif the space and the freedom to do lots of things independently. For the final performance, for example, he chose to produce a poem about a T-Rex (drawing on his pre-existing obsession with dinosaurs), an idiosyncratic interpretation of the garden-themed brief which was happily embraced by Sally.

In their study of the 'signature' ways in which creative practitioners work in schools, Thomson et al (2012) note that teachers were frequently surprised by what children were able to achieve within an inclusive, creative pedagogy. During the end of project interview Lynne was visibly moved when reflecting upon Kashif's achievements. When comparing 
some of the writing Kashif had produced as part of the project with a recent sample of his school writing, Lynne pointed out the way in which Kashif had been able to play around more freely with ideas ranging in subject-matter from ladybirds and dinosaurs to beetroot (grown in the community garden). The rather messy piece of formally assessed writing we looked at was sketchy and undeveloped, starting with a formulaic 'once upon a time' and focusing in a perfunctory way on bullies and friendship. Based on his attainments to date Lynne's assessment of Kashif was someone who 'finds writing really frustrating and usually needs lots of support'. In contrast, his MoS 'Planting Poetry' notebook contained seven whole pages of carefully produced poems and drawings, an indication of the value Kashif gave to this creative activity.

\section{Conclusions}

Although Planting Poetry was a creative writing project (and all of the children in Lynne's class did indeed write poems), it is interesting that the actual final outcome was in the form of performance. The celebratory nature of the end of project event gave the children an exciting (and challenging) platform from which to share their compositions with parents and carers. The garden installation further raised the public visibility of their work, with pupils across the whole class voicing real pride in their achievements (overwhelmingly apparent, for example, in an end of project survey Lynne gave to the whole class). Doecke and McClenaghan $(2011,77)$ argue that creativity encompasses much more than individual 'gifts' or 'talents', however much curricular and assessment rubrics attempt to construct it in this way; instead, they suggest, it emerges out of the social relationships enacted in specific contexts, a coming together of pupils' meaning-making practices from both within and without a particular institutional setting. Sammy's nature poem, for example, acquires its full creative potential only in the context of the collective experiences in the community garden (including the final party), other broader curricular explorations (for instance, the Kew Gardens trip) and Sammy's own growing understanding of the possibilities afforded by the mesostic form to convey his ideas.

Importantly, this social, generative model of creativity was made possible by means of an inclusive pedagogy, which not only enabled everyone to participate fully in workshop activities but also set up the expectation that every child in the class was capable of responding imaginatively to stimuli, developing ideas and producing/performing her/his own poetry, albeit in different ways. Sally's consciously open, inclusive approach echoes that identified as a 'signature' pedagogy by Thomson et al (2012) in their analysis of creative practitioners at work with young people, a pedagogic move constructed as a direct challenge to the instrumental, ability-focused 'default pedagogies' (15) of standards-driven classrooms. 
Partnerships between creative practitioners and schools, however, are not unproblematic. Research literature suggests that teacher-practitioner relationships are complex, often unequal and, not surprisingly, commonly fraught with tensions (see, for instance, Burnard and Swann, 2010; Wyse, 2014). A number of factors enabled the Planting Poetry project to avoid some of the most common pitfalls, not least because Sally, Viv and Lynne laid the ground for a collaborative way of working at the initial planning meeting, based on a mutual recognition of each others' professional expertise. This helped to ensure that the project became embedded within the work of the class beyond the Thursday afternoon sessions and provided pupils with space for independent, extended periods of thinking and writing. Sally disrupted normal ways of working for the period of the project with Lynne as a willing partner. However, questions remain about the sustainability of the special events approach to creativity in schools and the way in which organisations such as the MoS relate to the mainstream curriculum. There is always the danger that short-term external interventions construct creative learning as a set of 'one-off bubbles' (Galton, 2010,63), cementing the place of creativity as a curricular bolt-on rather than an underpinning principle. Going back to the MoS website, it is easy to see that tensions might arise from the organisation's intention to help young people 'find their voices' whilst simultaneously committing themselves to 'complement teachers' work in their delivery of the statutory requirements' of the National Curriculum. What happens, for instance, where students' voices are antithetical to the aims of the curriculum or school? (See Thomson et al, 2006, for an account of a creative partnership which failed to overcome serious institutional tensions.)

And, finally, some thoughts about the choice of poetry as the focus of this creative writing project. In a major survey of poetry teaching in England (Ofsted, 2007), government inspectors identified it as an area of relative weakness within the English curriculum across both primary and secondary schools. In the face of frequent over-reliance on work-sheets and feature-spotting, inspectors praised writer residencies in schools. Research indicates that the teaching of poetry remains a persistently problematic aspect of the English curriculum (see, for example, Barrs and Styles, 2013; Dymoke et al, 2015). Sally's approach meant that poetry was offered to pupils as a potentially rich means of expression rather than a set of rules to be learnt. As argued by editors of an earlier issue of this journal, 'poetry has a distinctive value.... because of its ability to connect people's cognitive and affective responses, mind and body, experiences and memories' (Simecek and Rumbold, $2016,310)$. Sally's poetry teaching was unconstrained by rigid assessment objectives. This was poetry writing where feedback was almost always oral, from multiple sources. The project focus on 'mesostic' verse form provided a reassuring structure without limiting imaginative possibilities. It leant itself to the creation of sense-related moments of verse, free from the constraints of longer or more complex grammatical units. Above all, it enabled Lynne's pupils to play around with ideas, feelings and experiences in genuinely creative, liberating and exploratory ways.

Notes 
1. All names have been anonymised.

\section{References}

Banaji, S. and Burn, A. with Buckingham, D. 2010. The Rhetorics of Creativity: a Literature Review. Newcastle: Creativity Culture and Education.

Barrs, M. and Styles, M. 2013. "Afterword." In Making Poetry Matter: International Research on Poetry Pedagogy edited by S. Dymoke, A. Lambirth \& A. Wilson, 184-195. London: Bloomsbury.

Burnard, P. and Swann, M. 2010. Pupils' perceptions of learning with artists: a new order of experience? Thinking Skills and Creativity 5: 70-82.

DfE (Department for Education), 2014. National Curriculum in England: Framework for Key Stages 1-4. Available online at: https://www.gov.uk/government/publications/nationalcurriculum-in-england-framework-for-key-stages-1-to-4/the-national-curriculum-inengland-framework-for-key-stages-1-to-4 (accessed 22:10:16)

Doecke, B. and McClenaghan, D. 2011. Confronting Practice: classroom investigations into language and learning. Putney NSW: Phoenix Education.

Dymoke, S., Barrs, M., Lambirth, A. and Wilson, A. eds. 2015. Making Poetry Happen: transforming the poetry classroom. London: Bloomsbury.

Galton, M. 2010. Going with the flow or back to normal? The impact of creative practitioners in schools and classroom. Research Papers in Education 25 (4): 355-375.

Hall, C. and Thomson, P. 2007. Creative partnerships? Cultural policy and inclusive arts practice in one primary school. British Educational Research Journal 33(3): 315-329.

Jones, K. 2011. "Democratic creativity." In The International Handbook of Creative Learning, edited by J. Sefton-Green, P. Thomson, K. Jones \& L. Bresler, 129-139. London: Routledge.

Jones, R. and Wyse, D. eds. 2013. Creativity in the Primary Curriculum. London: Routledge. Matthewman, S. (2013) "Ecocritical approaches to writing nature poetry." In Making Poetry Matter: International Research on Poetry Pedagogy edited by S. Dymoke, A. Lambirth \& A. Wilson, 71-83. London: Bloomsbury.

Miles, M. and Huberman, M.A. 1994. Qualitative Data Analysis. Beverly Hills: Sage.

Ministry of Stories website: http://ministryofstories.org (accessed 22:10:16)

NACCCE. 1999. All Our Futures. London: DfEE 
Ofsted. 2007. Poetry in Schools: a survey of practice. London: Crown Copyright.

QCA. 2007. The National Curriculum: English. London: Qualifications and Curriculum Authority.

Simecek, K. and Rumbold, K. 2017. Editorial: The Uses of Poetry. Changing English 23 (4) 309-313.

Thomson, P., Hall, C., Jones, K. and Sefton-Green, J. 2012. The Signature Pedagogies Project: Final Report. London: Culture, Creativity \& Education.

Thomson, P., Hall, C. and Russell, L. 2006. An Arts Project Failed, Censored or...? A critical incident approach to artist-school partnerships, Changing English 13 (1): 29-44.

Wyse, D. 2014. Creativity and the Curriculum. An inaugural professorial lecture. London: Institute of Education Press.

Wyse, D., Bradford, H., Burn, A. and Wiggins, M. 2015. Young People Writing: A three-year longitudinal research evaluation of 'The Ministry of Stories' (MoS). Final report. Available online at: http://ministryofstories.org/programmes/for-schools/impact/ (accessed: 22:10:16).

Wyse, D. and Ferrari, A. 2014. Creativity and Education: comparing the national curricula of the states of the European union and the United Kingdom, British Educational Research Journal 41(1): 30-47.

\section{Notes on contributor:}

Jane Coles is a lecturer in Education at UCL's Institute of Education. She is joint Programme Leader for the MA English Education and contributes to the secondary English PGCE. Her current areas of research focus on creative literacies and the teaching of Shakespeare. 